\title{
Cost-effectiveness of tailored print communication, telephone motivational interviewing, and a combination of the two: results of an economic evaluation alongside the Vitalum randomized controlled trial
}

Hilde M van Keulen ${ }^{1 *}$, Judith E Bosmans ${ }^{2}$, Maurits W van Tulder ${ }^{2}$, Johan L Severens ${ }^{3}$, Hein de Vries ${ }^{1}$, Johannes Brug ${ }^{4}$, Ilse Mesters ${ }^{5}$

\section{Correction}

Since publication of our article [1], we have realized that Figure two (Figure 1): "Cost-effectiveness acceptability curve of difference in total number of guidelines met", is incorrect. The original text referring to the figure as well as the figure legend is correct. The correct Figure two

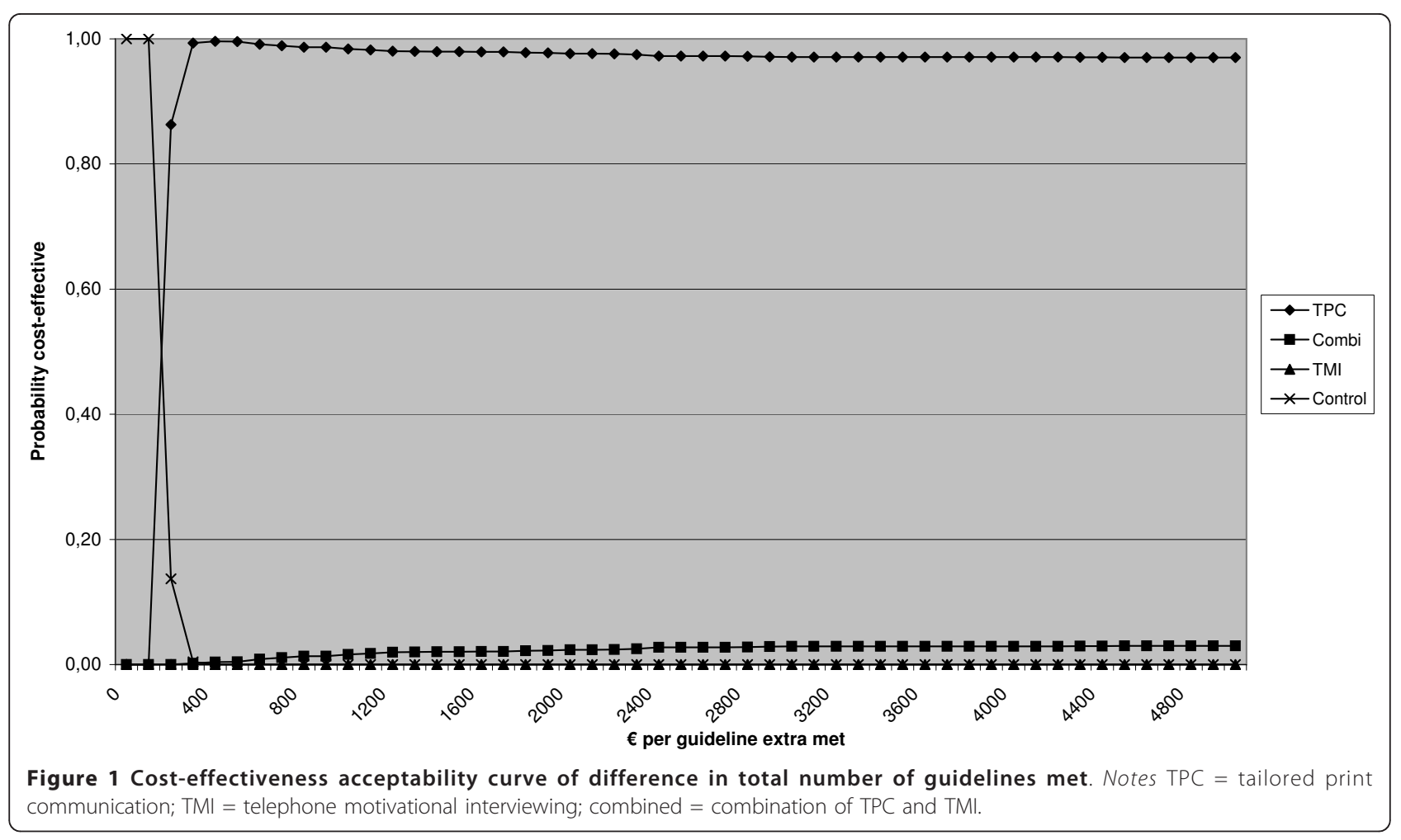

\footnotetext{
* Correspondence: hilde.vankeulen@tno.nl

'School for Public Health and Primary Care (Caphri), Department of Health

Promotion, Maastricht University, the Netherlands

Full list of author information is available at the end of the article
} 
(Figure 1) is displayed here. We apologise for any inconvenience or confusion this may have caused.

\section{Author details}

${ }^{1}$ School for Public Health and Primary Care (Caphri), Department of Health Promotion, Maastricht University, the Netherlands. ${ }^{2}$ Department of Health Sciences and EMGO Institute for Health and Care Research, VU University Amsterdam, the Netherlands. ${ }^{3}$ Institute for Health Policy and Management, Erasmus University Rotterdam, the Netherlands \& School for Public Health and Primary Care (Caphri), Department of Health Organization, Policy, and Economics, Maastricht University, Maastricht, the Netherlands. ${ }^{4}$ EMGO Institute for Health and Care Research, VU University Medical Centre, Amsterdam, the Netherlands. ${ }^{5}$ School for Public Health and Primary Care (Caphri), Department of Epidemiology, Maastricht University, the

Netherlands.

Received: 25 January 2011 Accepted: 26 January 2011

Published: 26 January 2011

\section{Reference}

1. Van Keulen HM, Bosmans JE, van Tulder MW, Severens JL, de Vries H, Brug J, Mesters I: Cost-effectiveness of tailored print communication, telephone motivational interviewing, and a combination of the two: results of an economic evaluation alongside the Vitalum randomized controlled trial. International Journal of Behavioral Nutrition and Physical Activity 2010, 7:64.

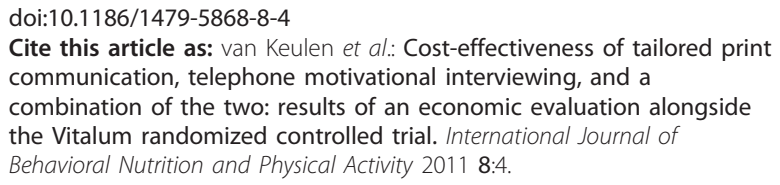

\section{Submit your next manuscript to BioMed Central and take full advantage of:}

- Convenient online submission

- Thorough peer review

- No space constraints or color figure charges

- Immediate publication on acceptance

- Inclusion in PubMed, CAS, Scopus and Google Scholar

- Research which is freely available for redistribution

Submit your manuscript at www.biomedcentral.com/submit 